\title{
Which non-fibrous carbohydrates: neutral detergent fiber ratio optimizes the use of cactus cladodes in diets of growing heifers?
}

\section{Qual relação carboidratos não fibrosos: fibra em detergente neutro otimiza o uso de palma forrageira em dietas para novilhas em crescimento?}

\begin{abstract}
Airon Aparecido Silva de Melo'; Dulciene Karla de Andrade Silva ${ }^{1} ;$ André Luiz Rodrigues Magalhães ${ }^{1}$; Fábia Simone Bezerra Cordeiro2; Gabriel Henrique Oliveira Almeida ${ }^{3}$; Gláucia Sabrine de Oliveira Moraes4; Daniel Barros Cardoso ${ }^{5 *}$; Pedro Henrique Borba Pereira ${ }^{2}$
\end{abstract}

\section{Highlights}

The NFC and TDN intakes increased with elevation of the NFC:NDF ratio.

The NDF digestibility decreased with increasing NFC levels in diets.

Chewing time and feeding efficiency of NDF decreased with elevation of the NFC.

The ruminal $\mathrm{pH}$ showed the lowest values at 4 hours after feeding.

The number of ruminal protozoa increased $64.5 \%$ with elevation of the NFC:NDF ratio.

\section{Abstract}

This study aimed to evaluate the effect of different non-fibrous carbohydrate (NFC):neutral detergent fiber (NDF) ratios $(0.70: 1,0.90: 1,1.14: 1,1.42: 1$, and 1.85:1) in diets containing cactus cladodes on intake, digestibility, ruminal parameters, ingestive behavior, and microbial protein of growing heifers. Five rumencannulated heifers (194 $\pm 70 \mathrm{~kg}$ of body weight) were distributed in a Latin square design (5 $\times 5)$. There was a quadratic effect on the intake of dry matter (DM) (Kg day ${ }^{-1}$ and \%BW) and crude protein (CP) with the increase in non-fibrous carbohydrate (NFC): neutral detergent fiber (NDF) ratio, with maximum values of 7.07 $\mathrm{kg} \mathrm{day}^{-1}, 2.86 \%$, and $0.949 \mathrm{~kg} \mathrm{day}^{-1}$, estimated for 1.37:1, 1.39:1, and 1.27:1 ratios. When the intake of NDF

1 Profs. Drs., Universidade Federal do Agreste de Pernambuco, UFAPE, Garanhuns, PE, Brazil. E-mail: airon.melo@ ufape.edu.br; karla.silva@ufape.edu.br; andre.magalhaes@ufape.edu.br

2 Master's Students of the Animal Science and Pastures Postgraduate Program, UFAPE, Garanhuns, PE, Brazil. E-mail: fabiasimone_3@hotmail.com; pedro.borba.pereira@gmail.com

${ }^{3}$ PhD Student of the Integrated Doctoral in Animal Science Program, Universidade Federal da Paraíba, UFPB, Areia, PB, Brazil. E-mail: gabrielh18@hotmail.com

${ }_{4}^{4} \mathrm{PhD}$ Student of the Integrated Doctoral in Animal Science Program, Universidade Federal Rural de Pernambuco, UFRPE, Recife, PE, Brazil. E-mail: gsomoraes@gmail.com

5 Researcher PNPD/Capes, Animal Science and Pastures Postgraduate Program, UFAPE, Garanhuns, PE, Brazil. E-mail: danbarrc@hotmail.com

* Author for correspondence

Received: Mar. 22, 2021 - Approved: Sept. 16, 2021 
decreased, in turn, the intakes of NFC and TDN increased. The NDF digestibility decreased with increasing NFC levels in diets. The other nutrients were not influenced. The ruminal $\mathrm{pH}$ showed the lowest values at 4 hours after feeding, mainly for animals fed the 1.85:1 ratio. There was a quadratic effect for rumination time with maximum values estimated for an NFC:NDF ratio of 0.88:1. The time spent idle increased linearly, while total chewing time and feeding efficiency of NDF decreased. The urinary volume increased linearly. However, microbial protein synthesis and the efficiency of the synthesis were not influenced. The number of protozoa increased by $64.5 \%$ with the elevation of the NFC:NDF ratio. We recommend a NFC:NDF ratio of 1.37:1 in diets containing cactus cladodes, to improve the use of nutrients, without negatively affecting ruminal parameters.

Key words: Cactaceae. Effective fiber. Protozoa. Ruminal pH. Rumination. Semiarid.

\section{Resumo}

Este estudo teve como objetivo avaliar o efeito de diferentes relações carboidratos não fibrosos (CNF): fibra em detergente neutro (FDN) $(0,70: 1 ; 0,90: 1 ; 1,14: 1 ; 1,42: 1$ e 1,85: 1$)$ em dietas contendo palma forrageira sobre o consumo, digestibilidade, parâmetros ruminais, comportamento ingestivo e proteína microbiana de novilhas em crescimento. Cinco novilhas, fistuladas no rúmen (194 $\pm 70 \mathrm{~kg}$ de peso corporal) foram distribuídas em um delineamento em quadrado latino $(5 \times 5)$. Houve efeito quadrático sobre o consumo de matéria seca (MS) (kg dia-1 (\% PC) e proteína bruta (PB) com o aumento da relação carboidratos não fibrosos (CNF): fibra em detergente neutro (FDN), com valores máximos de 7,07 kg dia-1, 2,86\% e 0,949 kg dia-1, estimado para 1,37: 1; 1,39: 1 e proporção de 1,27: 1 . Enquanto a ingestão de FDN diminuiu, a ingestão de CNF e NDT aumentou. A digestibilidade da FDN diminuiu com o aumento dos teores de FDN nas dietas. Os demais nutrientes não foram influenciados. $\mathrm{O}$ pH ruminal apresentou os menores valores 4 horas após a alimentação, principalmente para os animais alimentados na proporção de 1,85: 1. Houve efeito quadrático para o tempo de ruminação com valores máximos estimados para uma relação CNF: FDN de 0,88: 1. 0 tempo de ócio aumentou linearmente, enquanto o tempo total de mastigação e a eficiência alimentar da FDN diminuíram. O volume urinário aumentou linearmente. No entanto, a síntese de proteína microbiana e a eficiência da síntese não foram influenciadas. O número de protozoários aumentou $64,5 \%$ com a elevação da relação CNF: FDN. Recomenda-se a relação CNF:FDN de 1,37: 1 em dietas contendo palma forrageira, para melhorar o aproveitamento dos nutrientes, sem afetar negativamente os parâmetros ruminais.

Palavras-chave: Cactaceae. Semiárido. Fibra efetiva. Protozoários. pH ruminal. Ruminação.

\section{Introduction}

In milk production systems, the heifer rearing phase generates greater expenditure on feed, indicating an investment that is offset by the production phase (Gonzaga, Pimenta, \& Leite, 2011). Additionally, this investment is linked to the category's feed, since the feed favors the bodyand physiological development of heifers, meeting the requirements for weight gain and maintenance (National Research Council [NRC], 2001).

The ratio of fibrous and non-fibrous carbohydrates should be explored in the production of heifers to improve production efficiency without losses, such as late growth, implying age at first calving. One way to achieve this relationship is the association of different roughage and/or concentrated foods. However, in arid and semiarid regions 
there is a limitation on the production of forage resources in the production of fodder, due to the irregularity in the distribution of rain, making it important to use forage species adapted to these conditions.

The cactus cladodes (Opuntia and Nopalea) have become one of the most important energy sources in dairy farms of semiarid regions (Monteiro et al., 2018; Soares et al., 2020). This cactus has high values of non-fibrous carbohydrates (528-545 g kg-1 of dry matter (DM)), low values of crude protein (CP) (51-64 $\mathrm{g} \mathrm{kg}^{-1}$ of DM), and neutral detergent fiber (257-272 $\mathrm{g} \mathrm{kg}^{-1}$ of DM) (Barros et al., 2018; Moraes et al., 2019). Furthermore, this plant presents DM and NDF disappearances of 606 $\mathrm{g} \mathrm{kg}^{-1}$ of DM and $611 \mathrm{~g} \mathrm{~kg}^{-1}$ of NDF, after 12 and 48 hours of ruminal incubation, respectively (Batista, Mustafa, Wang, Soita, \& McKinnon, 2003). Therefore, association with other fiber sources must be recommended (Siqueira et al., 2017).

The non-fibrous carbohydrate (NFC): neutral detergent fiber (NDF) ratio in a diet has a direct effect on the intake of DM, ruminal health, $\mathrm{NH}_{3}-\mathrm{N}$, volatile fatty acids, microbial population (Ma, Tu, Zhang, Deng, \& Diao, 2015; $\mathrm{Pu}$ et al., 2020), and nutrient digestibility, consequently exerting effects on the growth and productivity of ruminants. The NRC (2001) recommends a maximum content of $440 \mathrm{~g} \mathrm{~kg}^{-1}$ of NFC, and a minimum content of $210 \mathrm{~g} \mathrm{~kg}^{-1}$ of physically effective NDF to maintain adequate ruminal functioning.

It was hypothesized that there is an NFC:NDF ratio that optimizes nutrient intake and utilization, without negatively affecting the ruminal environment for growing heifers. Thus, the objective of this study was to evaluate the influence of different non-fibrous carbohydrate (NFC):neutral detergent fiber (NDF) ratios in the diets of growing heifers on intake, digestibility,
$\mathrm{pH}$ and protozoa amount, ingestive behavior, and microbial protein synthesis.

\section{Material and Methods}

The experiment was carried out at the Bovine Clinic belonging to the Federal Rural University of Pernambuco (UFRPE), in the municipality of Garanhuns in the state of Pernambuco, located in the Microregion of Agreste. All procedures were conducted following the guidelines set by the Ethics Committee on Use of Animals for Research (CEUA) of the UFRPE.

Five rumen fistulated heifers ( $1 / 2$ Holstein-Zebu) with an average initial body weight (BW) of $194 \pm 70 \mathrm{Kg}$ were assigned in a $5 \times 5$ Latin square design. The animals were weighed, identified, and vermifuged before the start of the experiment and housed in individual pens fitted with feeders and waterers. The trial lasted for 100 days, with five consecutive 20day periods divided into 15-day adaptation and five-day sampling periods.

The animals were fed twice daily (at 07h00 and 17h00). The amount of feed supplied was corrected daily to generate $5 \%$ to $10 \%$ of orts. Feeds and orts were weighed daily throughout the experimental period to calculate the voluntary intake.

The experimental treatments consisted of five different proportions of non-fibrous carbohydrates (NFC) and neutral detergent fiber (NDF) $(0.70: 1,0.90: 1,1.14: 1$, 1.42:1, and 1.85:1), with levels $(0.0,12.5,25.0$, 37.5 , and $50.0 \%$ ) of cactus cladodes (Opuntia fícus indica Mill) replacing by elephant grass (Pennisetum purpureum Schum) at contents of $(0,25,50,75$, and $100 \%$ based on dry matter (DM)). The roughage, elephant grass, and cactus cladodes were used in different 
proportions to modify the ratios of NFC and NDF. The experimental diets were formulated considering the food composition and protein requirements for a weight gain of $800 \mathrm{~g} \mathrm{day}^{-1}$, according to the NRC (2001). The chemical composition of the ingredients and proportion of the ingredients and chemical composition of in the experimental diets are shown in Tables 1 and 2 .
The diet ingredients, orts, and feces samples were pooled per animal and experimental period and stored in plastic bags at $-20^{\circ} \mathrm{C}$. At the end of the experiment, the samples were oven-dried at $60^{\circ} \mathrm{C}$ for 72 hours and ground to pass through a $2 \mathrm{~mm}$ mesh for in situ ruminal incubation and through a $1 \mathrm{~mm}$ screen for further chemical analyses.

\section{Table 1}

Chemical composition of diet ingredients

\begin{tabular}{|ccccccc} 
Item & $\begin{array}{c}\text { Cactus } \\
\text { cladodes }\end{array}$ & $\begin{array}{c}\text { Elephant } \\
\text { grass }\end{array}$ & $\begin{array}{c}\text { Ground } \\
\text { corn }\end{array}$ & $\begin{array}{c}\text { Wheat } \\
\text { Bran }\end{array}$ & $\begin{array}{c}\text { Soybean } \\
\text { oil }\end{array}$ & Urea \\
\hline Dry matter & 7.30 & 21.8 & 84.7 & 88.0 & 99.6 & 99.0 \\
Crude protein & 4.5 & 9.5 & 9.6 & 18.5 & - & 280.0 \\
Ether extract & 1.94 & 1.73 & 4.01 & 3.53 & 99.0 & - \\
Neutral detergent fiber & 21.0 & 76.2 & 11.6 & 44.0 & - & - \\
Non-fibrous carbohydrates & 59.9 & 3.3 & 73.3 & 26.5 & - & -
\end{tabular}

\section{Table 2}

Proportion and chemical composition of experimental diets (based on DM)

\begin{tabular}{|cccccc|}
\hline & \multicolumn{5}{c}{ NFC: NDF ratio } \\
\hline Ingredients & $0.70: 1$ & $0.90: 1$ & $1.14: 1$ & $1.42: 1$ & $1.85: 1$ \\
\hline Cactus cladodes & 0.0 & 12.5 & 25.0 & 37.5 & 50.0 \\
\hline Elephant grass & 50.0 & 37.5 & 25.0 & 12.5 & 0.0 \\
\hline Ground corn & 35.6 & 31.2 & 26.2 & 19.9 & 15 \\
\hline Wheat bran & 10.0 & 15.0 & 20.6 & 27.5 & 33.0 \\
\hline Soybean oil & 2.4 & 1.8 & 1.2 & 0.6 & 0.0 \\
\hline Mineral mix & 1.0 & 1.0 & 1.0 & 1.0 & 1.0 \\
Urea & 1.0 & 1.0 & 1.0 & 1.0 & 1.0 \\
\hline Chemical composition & & & & & \\
\hline Dry matter & & 25.0 & 19.4 & 15.9 & 13.5 \\
\hline Crude protein & 12.8 & 12.7 & 12.6 & 12.7 & 12.6 \\
\hline Ether extract & 5.04 & 4.47 & 3.89 & 3.31 & 2.73 \\
\hline Non-fibrous carbohydrates & 32.8 & 37.3 & 41.6 & 45.3 & 49.7 \\
\hline Neutral detergent fiber & 46.6 & 41.4 & 36.4 & 31.8 & 26.8 \\
\hline NDF ${ }^{2}$ elephant grass & 38.0 & 28.5 & 19.0 & 9.5 & 0.0 \\
\hline Total digestible nutrients & 68.2 & 68.5 & 68.8 & 69.0 & 69.3 \\
\hline
\end{tabular}

$1 \%$ of natural matter. 2 NDF = Neutral detergent fiber. 
For estimated apparent digestibility and total digestible nutrients (TDN) concentration, spot fecal samples were collected directly from the animals' rectums, and the samples were pooled per animal and experimental period, and stored at $-20{ }^{\circ} \mathrm{C}$ for chemical analyses. Fecal excretion was estimated using the indigestible NDF (iNDF) as an internal marker. The feces, feed, and orts' iNDF contents were obtained after 288 hours of ruminal incubation 288 hours (INCT-CA n. F-009/1 method) (Detmann et al., 2012).

The samples of the feed and orts were analyzed for chemical composition through the INCT-CA methods to determine dry matter (DM; G-003/1), mineral matter (MM; M-001/1), crude protein (CP; Kjeldahl method; N 001/1), ether extract (EE; G-004/1), and neutral detergent fiber (NDFap; F-002/1), according to the methodologies described by Detmann et al. (2012)

For the estimation of non-fibrous carbohydrates (NFC), the equation proposed by Hall (2000) was used:

$$
\begin{aligned}
\text { NFC }\left(\mathrm{g} \mathrm{kg}^{-1}\right)= & 1000-(\text { ash }+ \text { EE }+ \text { NDFap }+ \\
& (\text { CP }- \text { CPu }+ \text { U) })
\end{aligned}
$$

where: NDFap $=$ neutral detergent fiber corrected for ash and protein; $\mathrm{CPu}=$ crude protein content from urea; $\mathrm{U}=$ urea content.

For estimating the concentration of total digestible nutrients (TDN), the equation described by Weiss (1999) was adopted, in which:

$$
\begin{aligned}
\text { TDN }\left(\mathrm{g} \mathrm{kg}^{-1}\right)= & (\mathrm{CPd}+\mathrm{NDFapd}+\mathrm{NFCd}+ \\
& \mathrm{EEd} * 2.25)
\end{aligned}
$$

where: $\mathrm{CPd}$ = digestible crude protein; NDFapd = digestible neutral detergent fiber corrected for ash and protein; NFCd = digestible nonfibrous carbohydrate; and EEd = digestible ether extract.

Urine spot samples were obtained from all heifers on the eighteenth day of the second experimental period, during spontaneous urination, approximately 4 hours after their morning feeding. The urine was filtered through gauze and an aliquot of $10 \mathrm{~mL}$ was diluted immediately in $40 \mathrm{~mL}$ of $\mathrm{H}_{2} \mathrm{SO}_{3}(0.036$ $\mathrm{N})$. The samples were stored at $-20{ }^{\circ} \mathrm{C}$ for further nitrogen, urea, allantoin ( $A L)$, uric acid (UA), and creatinine analysis.

To analyze $A L$ in urine, the colorimetric method as described by Chen and Gomes (1992) was used. The urea concentration in urine was analyzed via the enzymaticcolorimetric system of the urease method, the UA concentration in urine was analyzed via the enzymatic Trinder method, and the creatinine concentration in urine was analyzed using "end point" markers with picrate and acidification, both using commercial kits (Labtest Diagnóstica ${ }^{\circledR}$ S.A.).

According to Valadares and Valadares (2001), the total urinary volume was estimated by dividing the urinary excretion of creatinine by the value observed for urine creatinine concentration. Creatinine excretion (CE) was estimated by using a mathematical model proposed by Chizzotti, Valadares, Diniz Valadares, Chizzotti and Thedeschi (2008):

$\mathrm{CE}\left(\mathrm{mg} \mathrm{kg} \mathrm{BW}{ }^{-1}\right): 32.27-0.01093^{*} \mathrm{BW}$.

The total excretion of purine derivatives (PD) was obtained from the sum of urinary excretions of allantoin and uric acid. The absorption of microbial purines ( $\mathrm{X}, \mathrm{mmol} / \mathrm{d}$ ) was calculated from the excretion of purine derivatives $(\mathrm{Y}, \mathrm{mmol} / \mathrm{d})$ by using the equation: 


$$
Y=0.85 X+0.385^{*} B W^{0.75}
$$

where: 0.85 is the recovery of absorbed purines as purine derivatives in the urine, and $0.385^{*} \mathrm{BW}^{0,75}$ is the endogenous purine derivatives' excretion in the urine.

The intestinal flow of microbial nitrogen compounds ( $Y, g$ of $\mathrm{N}$-day) was calculated as a function of the absorbed purines $(X, \mathrm{mmol}$ dia $^{-1}$ ), by using the equation:

$$
Y=(70 X) /(0.83 \times 0.116 \times 1000)
$$

where: the number 70 represents purine $\mathrm{N}$ content $\left(\mathrm{mgN} \mathrm{mmol}{ }^{-1}\right)$; the number 83 represents the microbial purine digestibility; and the decimal number 0.116 represents the NRNA-NTotal ratio in the microorganisms (Chen \& Gomes, 1992).

To determinetheruminal $\mathrm{pH}$, collections of ruminal content were carried out for five days, every 26 hours. Samples of the ruminal digest were taken, corresponding to 0 hours (immediately before the feed was supplied) and at $2,4,6$, and 8 hours after morning food. The samples were collected directly via ruminal fistula at various points in the rumen, forming a sample composed of $400 \mathrm{ml}$. The material was placed on three layers of tissue and squeezed strongly to extract the liquid, taking an aliquot of approximately $90 \mathrm{~mL}$ in which, immediately, the $\mathrm{pH}$ was measured using a potentiometer (Kasavi, Modelo K39-0014P, Taiwan).
The variables studied were analyzed with the PROC MIXED option in the Statistical Analysis System Institute [SAS Institute] (2015) software (version 9.1.3, SAS Institute Inc., Cary, NC, USA). After the analysis of variance, the significance of the linear and quadratic effects was evaluated adopting a 5\% significance level for type I errors, according to the following model:

$$
Y i j k l=\mu+T i+Q j+P k+(A / Q) l j+T^{*} Q i j+\varepsilon i j k l
$$

where: Yijkl = observation $\mathrm{ijkl} ; \mu=$ over mean; $\mathrm{Ti}$ $=$ fixed effect of treatment $\mathrm{i} ; \mathrm{Qj}=$ fixed effect of square $\mathrm{j} ; \mathrm{Pk}=$ random effect of period $\mathrm{k} ;(A / Q)$ $I=$ random effect of animal I into square $j ; T^{*} Q i j$ = random effect of treatment $\mathrm{i}$ and square $\mathrm{j}$ interaction; $\varepsilon i j \mathrm{kl}=$ random residual error.

\section{Results and Discussion}

There was a quadratic effect $(P<0.05)$ on the intake of dry matter (DM) (kg/day and \%BW) and crude protein (CP) with maximum values of $7.07 \mathrm{~kg} \mathrm{day}^{-1}, 2.86 \%$, and 0.949 $\mathrm{kg} \mathrm{day}^{-1}$, estimated for NFC:NDF ratios of 1.37:1, 1.39:1, and 1.27:1. The intake of ether extract (EE) and neutral detergent fiber (NDF) (kg day ${ }^{-1}$ and \%BW) decreased linearly $(P<$ $0.05)$ with elevation of the NFC:NDF ratio. The non-fibrous carbohydrates (NFC) and total digestible nutrient (TDN) intakes increased linearly $(P<0.05$, Table 3$)$. 
Table 3

Intake and digestibility of dry matter and nutrients by heifers fed with different NFC: NDF ratios

\begin{tabular}{|c|c|c|c|c|c|c|c|c|}
\hline \multirow[b]{2}{*}{ Ingredients } & \multicolumn{5}{|c|}{ NFC: NDF ratio } & \multirow{2}{*}{ SEM } & \multicolumn{2}{|c|}{$P$-value } \\
\hline & 0.70:1 & $0.90: 1$ & $1.14: 1$ & $1.42: 1$ & $1.85: 1$ & & L & Q \\
\hline \multicolumn{9}{|c|}{ Intake (Kg day $\left.{ }^{-1}\right)$} \\
\hline Dry matter & 5.75 & 6.81 & 6.78 & 7.03 & 6.51 & 0.172 & 0.008 & 0.0011 \\
\hline Crude protein & 0.78 & 0.84 & 0.84 & 0.86 & 0.78 & 0.017 & 0.492 & 0.0022 \\
\hline Ether extract & 0.32 & 0.30 & 0.25 & 0.22 & 0.16 & 0.008 & 0.0013 & 0.117 \\
\hline NDF & 2.59 & 2.75 & 2.55 & 2.02 & 1.43 & 0.146 & 0.0014 & 0.067 \\
\hline NFC & 1.74 & 2.43 & 2.58 & 3.44 & 3.68 & 0.174 & 0.0015 & 0.779 \\
\hline NDT & 3.88 & 4.69 & 4.43 & 4.84 & 4.56 & 0.200 & 0.0346 & 0.066 \\
\hline Dry matter (\% BW) & 2.29 & 2.71 & 2.79 & 2.82 & 2.65 & 0.048 & 0.004 & 0.0017 \\
\hline NDF (\% BW) & 1.04 & 1.09 & 1.03 & 0.81 & 0.57 & 0.084 & 0.0018 & 0.035 \\
\hline \multicolumn{9}{|c|}{ Digestibility $\left(\mathrm{g} \mathrm{kg}^{-1}\right)$} \\
\hline Dry matter & 583.7 & 601.0 & 582.2 & 621.0 & 619.3 & 3.162 & 0.380 & 0.871 \\
\hline Crude protein & 636.0 & 616.1 & 570.4 & 641.6 & 588.3 & 2.812 & 0.446 & 0.643 \\
\hline Ether extract & 638.0 & 677.8 & 710.0 & 681.7 & 658.0 & 6.976 & 0.846 & 0.486 \\
\hline NDF & 595.8 & 602.7 & 551.6 & 435.5 & 351.1 & 3.987 & 0.0019 & 0.123 \\
\hline NFC & 830.6 & 804.2 & 803.4 & 868.8 & 893.9 & 4.165 & 0.172 & 0.299 \\
\hline
\end{tabular}

NDF $=$ Neutral detergent fiber, NFC = Non-fibrous carbohydrates, SEM = Standard error of the mean,

${ }^{1} \hat{Y}=2.18+7.1213 X-2.5945 X^{2}$

${ }^{2} \hat{Y}=0.58+0.5821 X-0.2294 X^{2}$

${ }^{3} \hat{Y}=0.42-0.1413 X$

${ }^{4} \hat{Y}=3.62-1.1317 X$

$5 \hat{Y}=0.75+1.6787 X$

$6 \hat{Y}=3.93+0.4558 X$

$7 \hat{Y}=0.73+3.0778 X-1.1101 X^{2}$

$8 \hat{Y}=1.45-0.4533 X$

${ }^{9} \hat{Y}=795.9-236.78 X$.

The quadratic behavior observed on DM intake, with a maximum point for the 1.37:1 ratio of NFC:NDF, possibly occurred due to the reduction of NDF contents (46.6 to 26.8 in the DM) and elevation of the NFC contents (32.8 to 49.7 in the DM) of the diets (Table 1). The cactus cladodes had a high rate of ruminal degradation, mainly from DM, favoring the maximization of the fermentative capacity due to the high content of NFC, whereas, with higher levels of fiber in diets, digestion is slower, the content remains in the rumen for longer periods, limiting rumen capacity (Siqueira et al., 2017).

However, from the 1.37:1 ratio, the DM intake decreased due to the higher energy intake, since the TDN intake increased. There may have been a physiological regulation of DM intake due to excess energy, when meeting the animal's energy requirements, or also by molecules that can influence satiety. It is known that with ruminal fermentation, volatile 
fatty acids are produced, which is influenced by the substrates used by microorganisms present in the rumen, and these volatile acids can influence feed ingestion, due to an effect of physiological regulations. Lins et al. (2016) observed values of $34.5 \mathrm{mmol} \mathrm{L}^{-1}$ of acetate, $15.3 \mathrm{mmol} \mathrm{L}^{-1}$ of propionate, and $6 \mathrm{mmol} \mathrm{L}^{-1}$ of butyrate, when replacing wheat bran with cactus cladodes at contents of 70.6, 54.2, and $57.5 \%$, respectively. However, Siqueira et al. (2017) and Pinho et al. (2018) did not observe any change in the proportion of volatile fatty acids with increased inclusion of cactus cladodes in the diets of goats and cattle, respectively.

Another hypothesis to reduce the intake of DM, after the maximum point is the cactus cladodes water content, which promotes a rumen filling effect. Previous research has also noted quadratic behavior on DM intake with increased levels of cactus cladodes in the diets of cattle (Conceição et al., 2016; Siqueira et al., 2017), sheep (Cardoso et al., 2019; Maciel et al., 2019), and goats (Pinho et al., 2018).

Consequently, with the increase in the NFC:NDF ratio, the intake of NFC increased and that of NDF decreased (Table 3), due to the replacement of elephant grass by cactus cladodes, since the latter has a higher NFC content and a lower NDF content (Table 1). Thus, due to the increase in NFC intake, the NDT intake increased.
The NDF digestibility decreased linearly $(P<0.05)$ with elevation of the NFC:NDF ratio in the diets (Table 3 ). On the other hand, the digestibility of DM, CP, EE, and NFC was unaltered $(P>0.05)$. Therefore, due to the increase in the intake of NFC, the digestibility of fiber decreased, possibly due to the shorter duration of the diet in the rumen with the increase in the NFC:NDF ratio, as fiber has a direct effect on the digestion rate of the diet (Siqueira et al., 2017). Other studies have also observed reduced NDF digestibility with the inclusion of cactus cladodes in cattle diets (Barros et al., 2018; Siqueira et al., 2017).

The $\mathrm{pH}$ decreased linearly with the increase of the NFC:NDF ratio $(P<0.05)$ and showed the lowest values at 4 hours after feeding $(P<0.05)$, mainly for the liquid animals fed with the 1.85:1 ratio of NFC: NDF (Figure 1). The reduction in ruminal $\mathrm{pH}$ with the increase in the NFC:NDF ratio, especially at 4 hours after feeding (Figure 1), may be related to the effect of NFC on the fermentative profile, being related to less rumination and total chewing, incorporating less saliva into the rumen environment (Table 4). Siqueira et al. (2017) observed lower $\mathrm{pH}$ values in the rumen liquid of cattle fed increasing contents of cactus cladodes. The same was observed by Pinho et al. (2018) and Lima et al. (2019) working with goats and sheep fed on cactus cladodes. 


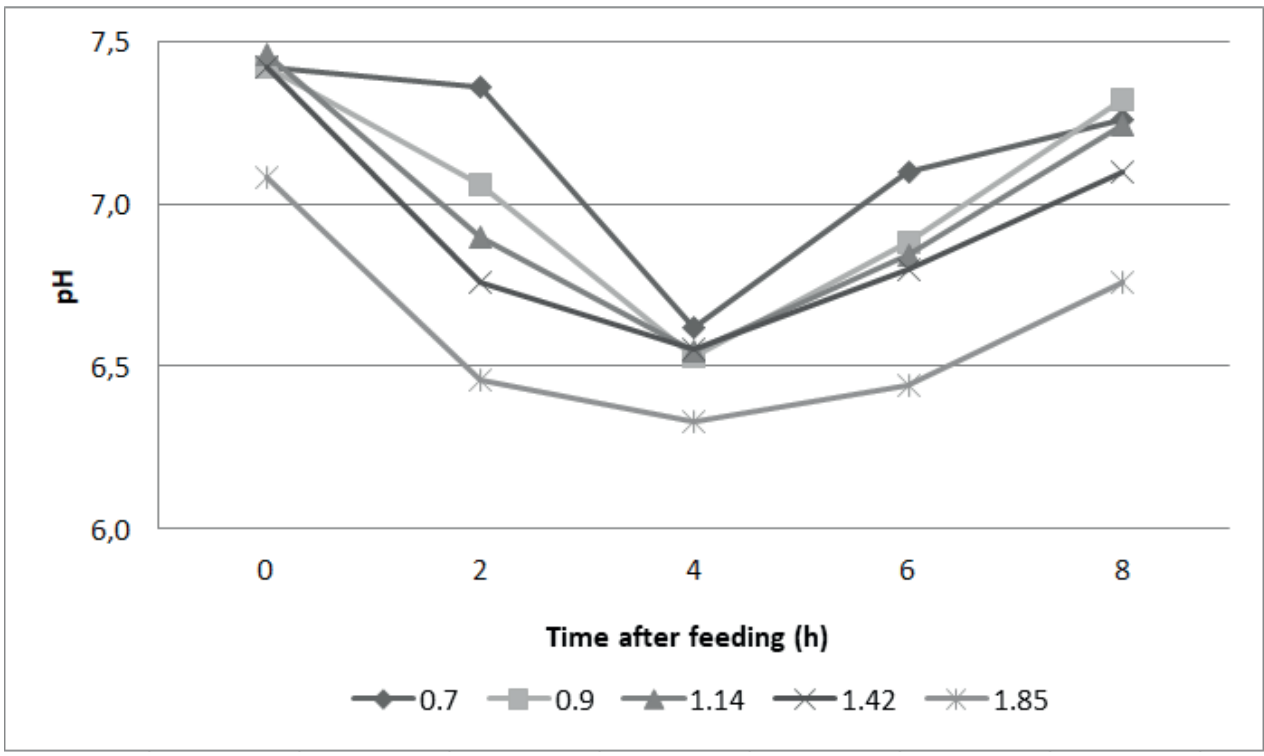

Figure 1. Variation of ruminal $\mathrm{pH}$ of heifers fed with different NFC: NDF ratios as a function of time after feeding.

The time spent feeding was unchanged $(P>0.05)$. There was a quadratic effect $(P$ $<0.05)$ for rumination time with maximum

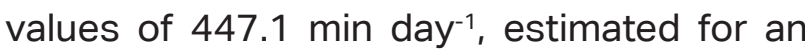
NFC:NDF ratio of 0.88:1. The time spent idle and rumination efficiency of DM increased linearly $(P<0.05)$, while total chewing time and feeding efficiency of NDF decreased linearly with the increase of the NFC:NDF ratio $(P<$ 0.05, Table 4).

Table 4

Ingestive behavior and feeding efficiency and rumination of heifers fed with different NFC: NDF ratios

\begin{tabular}{|c|c|c|c|c|c|c|c|c|}
\hline \multirow[b]{2}{*}{ Ingredients } & \multicolumn{5}{|c|}{ NFC: NDF ratio } & \multirow{2}{*}{ SEM } & \multicolumn{2}{|c|}{ P-value } \\
\hline & $0.70: 1$ & 0.90:1 & $1.14: 1$ & $1.42: 1$ & $1.85: 1$ & & $L$ & $Q$ \\
\hline Feeding time ${ }^{a}$ & 5.75 & 6.81 & 6.78 & 7.03 & 6.51 & 0.172 & 0.008 & 0.0011 \\
\hline Rumination time ${ }^{a}$ & 0.78 & 0.84 & 0.84 & 0.86 & 0.78 & 0.017 & 0.492 & 0.0022 \\
\hline Idle time ${ }^{a}$ & 0.32 & 0.30 & 0.25 & 0.22 & 0.16 & 0.008 & 0.0013 & 0.117 \\
\hline Total chewing time ${ }^{a}$ & 2.59 & 2.75 & 2.55 & 2.02 & 1.43 & 0.146 & 0.0014 & 0.067 \\
\hline Feeding efficiency of $\mathrm{DM}^{\mathrm{b}}$ & 1.74 & 2.43 & 2.58 & 3.44 & 3.68 & 0.174 & 0.0015 & 0.779 \\
\hline Rumination efficiency of $\mathrm{DM}^{\mathrm{b}}$ & 3.88 & 4.69 & 4.43 & 4.84 & 4.56 & 0.200 & 0.0346 & 0.066 \\
\hline Feeding efficiency of NDFb & 2.29 & 2.71 & 2.79 & 2.82 & 2.65 & 0.048 & 0.004 & 0.0017 \\
\hline Rumination efficiency of NDF & 1.04 & 1.09 & 1.03 & 0.81 & 0.57 & 0.084 & 0.0018 & 0.035 \\
\hline
\end{tabular}

SEM = Standard error of the mean; a min. day ${ }^{-1} ; \mathrm{b} \mathrm{g} \mathrm{min}^{-1}$.

$1 \hat{Y}=312.5+306.51 X-174.5 X 2$

$2 \hat{Y}=653.50+120.87 X$

$3 \hat{Y}=377.7-1.092 X$

${ }^{4} \hat{Y}=1169.7+1379.4 X$

$5 \hat{Y}=0.98-0.3348 X$. 
In diets based on cactus cladodes, due to their processing in forage machinery, the mucilage is exposed which favors the adherence of particles of dietary ingredients, thus, promoting less time spent on feeding when compared to diets based on other fibrous roughage sources (Rezende et al., 2020; Siqueira et al., 2018). Despite this fact, it was observed in this study that there was no difference in the time spent on feeding, which may possibly be related to the particle size when the elephant grass was chopped, favoring better incorporation of the other ingredients, as well as the age of the grass.

The replacement of elephant grass by cactus cladodes favored an increase in the time spent on rumination up to the maximum point of 0.88 NFC:NDF, even with the reduction of the NDF intake of the diets. This was due to the intake of DM, which was quadratic, reducing the time spent with rumination after the maximum point, justified by the reduction in the time of total chewing and efficiency of the NDF ingestion that decreased with the increase of the NFC:NDF ratio. The concentration of NFC and its rapid ruminal degradation reduces ruminal movements and consequently, total chewing. Despite this, it was observed that the NDF rumination efficiency was unaltered, possibly due to the particle size and fiber quality of elephant grass. Similar results for the efficiency of NDF rumination were observed by Conceição et al. (2016) and Siqueira et al. (2018).

The urinary volume increased linearly $(P<0.05)$ with elevation of the NFC:NDF ratio. The microbial protein synthesis and synthesis efficiency were unaltered. On the other hand, the number of protozoa increased $(P<0.05)$ (Table 5).

\section{Table 5}

Urinary volume, synthesis and efficiency of microbial protein synthesis, and number of protozoa of heifers fed with different NFC: NDF ratios

\begin{tabular}{|c|c|c|c|c|c|c|c|c|}
\hline \multirow[b]{2}{*}{ Ingredients } & \multicolumn{5}{|c|}{ NFC: NDF ratio } & \multirow{2}{*}{ SEM } & \multicolumn{2}{|c|}{ P-value } \\
\hline & $0.70: 1$ & $0.90: 1$ & $1.14: 1$ & $1.42: 1$ & $1.85: 1$ & & $L$ & $Q$ \\
\hline Urinary volume $\left(\mathrm{L} \mathrm{day}^{-1}\right)$ & 8.47 & 8.86 & 16.54 & 24.20 & 18.31 & 8.470 & $0.021^{1}$ & 0.437 \\
\hline \multicolumn{9}{|c|}{ Microbial protein } \\
\hline Synthesis (g day ${ }^{-1}$ ) & 418.4 & 486.7 & 727.9 & 701.1 & 610.8 & 138.5 & 0.196 & 0.281 \\
\hline Efficiency $\left(\mathrm{kg} \mathrm{TDN}^{-1}\right)$ & 113.4 & 105.1 & 172.9 & 159.3 & 130.3 & 37.28 & 0.460 & 0.403 \\
\hline \multicolumn{9}{|c|}{ Protozoa $\left(\times 10^{5}\right)$} \\
\hline Total count (mL) & 1.6 & 3.3 & 4.8 & 4.1 & 4.7 & 0.827 & $0.021^{2}$ & 0.127 \\
\hline
\end{tabular}

SEM $=$ Standard error of the mean.

$1 \hat{Y}=1.7174-11.28 X$

${ }^{2} \hat{Y}=0.9816-2.2616 X$.

The increase in urinary volume may be related to the increase in water supply with the increase in NFC:NDF ratio, due to the increase in the amount of cactus cladodes in the diets (Table 2). The use of cactus cladodes in the ruminant diet leads to an increase in urinary 
volume (Barros et al., 2018; Cardoso et al., 2019; Rezende et al., 2020).

Microbial protein synthesis depends largely on the energy and nitrogen sources available in the rumen. As observed, the intake of CP was quadratic, following the DM intake (Table 3), and that even with an increase in the amount of NFC, a readily fermentable energy source in the rumen, the microbial protein synthesis was unaltered; so much so that the synthesis efficiency with an average value of 136.4 grams of Pmic kg-1 TDN, was close to the value of 120 grams of Pmic kg-1 TDN for cows in tropical conditions (Pina, Valadares, Valadares, \& Chizzotti, 2010). The increase in the rate of passage of the diet due to the increase in the NFC:NDF ratio may have provided a shorter time of activity of ruminal bacteria, providing ammonia for the synthesis of microbial protein.

The elevation in the population of protozoa $(65.9 \%$ higher) with the increase in the NFC:NDF ratio occurred due to the cactus cladodes' inclusion, promoting an increase in the rate of DM degradation in the rumen, which may have a rate disappearance of 606 $\mathrm{g} \mathrm{kg}-1$ of DM in 12 hours of ruminal incubation (Batista et al., 2003), similar to what occurs with concentrated foods. According to Franzolin and Dehority (1996), the number of protozoa increases with the elevation of concentrate content in the diet, and this population is influenced when the ruminal $\mathrm{pH}$ decreases. The reduction in $\mathrm{pH}$ values of the ruminal liquid (Figure 1) was apparently insufficient to influence the protozoa population.

Another hypothesis for the difference in the number of protozoa observed between the lowest and the highest NFC:NDF ratio, was the oil content in the diets since it was necessary to add this additional ingredient in the diet with a $0.70: 1$ ratio of NFC:NDF, to meet energy requirements. This inclusion was reduced as the NFC:NDF ratio was increased. The lipid supplementation has an inhibitory effect on ruminal microorganisms, notably protozoa (Granja-Salcedo et al., 2017a; Hartanto et al., 2017). Soybean oil can reduce the population of protozoa as it has rich unsaturated fatty acids and contains more than $50 \%$ linoleic acid (Granja-Salcedo et al., 2017b).

\section{Conclusion}

We recommend a non-fibrous carbohydrate (NFC):neutral detergent fiber (NDF) ratio of 1.37:1 in diets for improving the use of nutrients, without negatively affecting ruminal parameters.

\section{Acknowledgments}

The authors thank the Coordenação de Aperfeiçoamento de Pessoal de Nível Superior (CAPES), and Fundação de Amparo à Ciência e Tecnologia de Pernambuco (FACEPE) for granting graduate and postgraduate scholarship, and the Conselho Nacional de Desenvolvimento Científico e Tecnológico (CNPq) for funding this research.

\section{References}

Barros, L. J. A., Ferreira, M. A., Oliveira, J. C. V., Santos, D. C. S., Chagas, J. C. C., Alves, A. M. S. V.,... Freitas, W. R. F. (2018). Replacement of Tifton hay by spineless cactus in Girolando post-weaned heifers' diets. Tropical Animal Health and Production, 50(1), 149-154. doi: 10.1007/ s11250-017-1415-4 
Batista, A. M., Mustafa, A. F., Wang, Y., Soita, H., \& McKinnon, J. J. (2003). Effects of variety on chemical composition, in situ nutrient disappearance and in vitro gas production of spineless cacti. Journal of the Science of Food and Agriculture, 83(3), 140-145. doi: 10.1002/jsfa.1393

Cardoso, D. B., Carvalho, F. F. R., Medeiros, G. R., Guim, A., Cabral, A. M. D., Véras, R. M. L.,... Nascimento, A. G. O. (2019). Levels of inclusion of spineless cactus (Nopalea cochenillifera Salm Dyck) in the diet of lambs. Animal Feed Science and Technology, 247(1), 23-31. doi: 10.1016/j. anifeedsci.2018.10.016

Chen, X. B., \& Gomes, M. J. (1992). Estimation of microbial protein supply to sheep and cattle based on urinary excretion of purine derivatives- an overview of technical details. Aberdeen, UK: International Feed Research Unit. Rowett Research Institute.

Chizzotti, M. L., Valadares, S. C., Fo., Diniz Valadares, R. F., Chizzotti, F. H. M., \& Thedeschi, L. O. (2008). Determination of creatinine excretion and evaluation of spot urine sampling in Holstein cattle. Livestok Science, 113(2-3), 218-225. doi: 10.1016/j.livsci.2007.03.013

Conceição, G. C., Ferreira, M. A., Campos, J. M. S., Detmann, E., Siqueira, M. C. B., Barros, L. J. A., \& Costa, C. T. F. (2016). Replacement of wheat bran with spineless cactus in sugarcane-based diets for steers. Revista Brasileira de Zootecnia, 45(4), 158-164. doi: 10.1590/S1806-92 902016000400003

Detmann, E., Souza, M. A., Valadares, S. C., F'., Queiroz, A. C., Berchielli, T. T., Saliba, E. O. S.,... Azevêdo, J. A. G. (2012). Métodos para análise de alimentos. Instituto nacional de ciência e tecnologia de ciência animal. Visconde do Rio Branco: Suprema.

Franzolin, R., \& Dehority, B. A. (1996). Effect of prolonged high-concentrate feeding on ruminal protozoa concentrations. Journal Animal Science, 74(11), 2803-2809. doi: 10.2527/1996.74112803x

Gonzaga, S., Neto, Pimenta, E. C., Fo., \& Leite, F. H. S. (2011). Estratégia de manejo alimentar de vacas zebu de dupla função no Cariri e Agreste paraibano: inclusão de cana-de-açúcar e ureia em rações para vacas Guzará e Sindi em lactação. In L. J. F. Ximenes, Produção de bovinos no Nordeste do Brasil, desafios e resultados (pp. 263-298). Fortaleza, CE: Banco do Nordeste do Brasil.

Granja-Salcedo, Y. T., Messana, J. D., Souza, V. C., Dias, L. A. V., Kishi, L. T., Rocha, L. R., \& Berchielli, T. T. (2017a). Effects of partial replacement of maize in the diet with crude glycerin and/or soyabean oil on ruminal fermentation and microbial population in Nellore steers. British Journal of Nutrition, 118(9), 651-660. doi:10.1017/S0007114517002689

Granja-Salcedo, Y. T., Souza, V. C., Dias, L. A. V., Gomez-Insuasti, A. S., Messana, J. D., \& Berchielli, T. T. (2017b). Diet containing glycerine and soybean oil can reduce ruminal biohydrogenation in Nellore steers. Animal Feed Science and Technology, 225(3), 195-204. doi: 10.1016/j.anifeedsci.2017.01.021

Hall, M. B. (2000). Neutral detergent-soluble carbohydrates. Nutritional relevance and analysis. Gainesville: University of Florida. 
Hartanto, R., Cai, L., Yu, J., Zhang, N., Sun, L., \& Qi, D. (2017). Effects of supplementation with monensin and vegetable oils on in vitro enteric methane production and rumen fermentability of goats. Pakistan Journal of Agricultural Sciences, 54(3), 693-698. doi: 10.21162/PAKJAS/17.4347

Lima, T. J., Costa, R. G., Medeiros, G. R., Medeiros, A. N., Ribeiro, N. L., Oliveira, J. S.,... Carvalho, F. F. R. (2019). Ruminal and morphometric parameters of the rumen and intestines of sheep fed with increasing levels of spineless cactus (Nopalea cochenillifera Salm-Dyck). Tropical Animal Health and Production, 52(2), 363-368. doi: 10.1007/s11250-018-1697-1

Lins, S. E. B., Pessoa, R. A. S., Ferreira, M. A., Campos, J. M.S., Silva, J.A.B. A., Silva, J.L.,... Melo, T. T. B. (2016). Spineless cactus as a replacement for wheat bran in sugar canebased diets for sheep: intake, digestibility, and ruminal parameters. Revista Brasileira de Zootecnia, 45(1), 26-31. doi: 10.15 90/ S1806-92902016000100004

Ma, T., Tu, Y., Zhang, N. F., Deng, K. D., \& Diao, Q. Y. (2015). Effect of the ratio of non-fibrous carbohydrates to neutral detergent fiber and protein structure on intake, digestibility, rumen fermentation, and nitrogen metabolism in lambs. AsianAustralas Journal Animal Science, 28(10), 1419-1426. doi: 10.5713/ajas.15.0025

Maciel, L. P. A. A., Carvalho, F. F. R., Batista, Â. M. V., Guim, A., Maciel, M. V., Cardoso, D. C., \& Lima, D. M., Jr. (2019). Intake, digestibility and metabolism in sheep fed with increasing levels of spineless cactus (Nopalea cochenillifera Salm-Dyck). Tropical Animal Health and Production, 51(6), 1717-1723. doi: 10.1007/s11250019-01868-4
Monteiro, C. C. F., Ferreira, M. A., Véras, A. S. C., Guido, S. I., Almeida, M. P., Silva, R. C., \& Inácio, J. G. (2018). A new cactus variety for dairy cows in areas infested with Dactylopius opuntiae. Animal Production Science, 59(3), 479-485. doi: 10.1071/ AN17256

Moraes, G. S. O., Guim, A., Tabosa, J. N., Chagas, J. C. C., Almeida, M. P., \& Ferreira, M. A. (2019). Cactus [Opuntia stricta (Haw.) Haw] cladodes and corn silage: how do we maximize the performance of lactating dairy cows reared in semiarid regions? Livestock Science, 221(3), 133-138. doi: 10.1016/j. livsci.2019.01.026

National Research Council (2001). Nutrient requirements of dairy cattle (7nd ed.). Washington, D. C.: National Academic Press.

Pinho, R. M. A., Santos, E. M., Oliveira, J. S., Carvalho, G. G. P., Silva, T. C., Macêdo, A. J. S.,... Zanine, A. M. (2018). Does the level of forage neutral detergent fiber affect the ruminal fermentation, digestibility and feeding behavior of goats fed cactus pear? Animal Science Journal, 89(10), 1424-1431. doi: 10.1111/asj.13043

Pina, D. S., Valadares, R. F. D., Valadares, S. C., $F^{\circ}$., \& Chizzotti, M. L. (2010). Degradação ruminal da proteína dos alimentos e síntese de proteína microbiana. In S. C. Fo., Valadares, M. I. Marcondes, M. L Chizzotti, \& P. V. R. Paulino (Eds.), Exigências nutricionais de zebuínos e tabelas de composição de alimentos BR-Corte (2a ed., pp. 14-46). Viçosa, MG: Editora UFV.

Pu, X., Guo, X., Shahzad, K., Wang, M., Jiang, C., Liu, J.,... Cheng, L. (2020). Effects of dietary non-fibrous carbohydrate (NFC) to neutral detergent fiber (NDF) ratio change 
on rumen bacteria in sheep based on three generations of full-length amplifiers sequencing. Animals, 10(2), 192. doi: 10.3390/ani10020192

Rezende, F.M., Véras, A. S. C., Siqueira, M. C. B., Conceição, M. G., Lima, C. L., Almeida, M. P.,... Ferreira, M. A. (2020). Nutritional effects of using cactus cladodes (Opuntia stricta Haw Haw) to replace sorghum silage in sheep diet. Tropital Animal Health and Production, 52(4), 1875-1880. doi: 10.1007/s11250-020-02213-w

Statistical Analysis System (2015). User's guide, version 9.3. Cary, NC: SAS Institute Inc.

Siqueira, M. C. B., Ferreira, M. A., Monnerat, J. P. I. S., Silva, J. L., Costa, C. T. F., Conceição, M. G.,... Melo, T. T. B. (2017). Optimizing the use of spineless cactus in the diets of cattle: total and partial digestibility, fiber dynamics and ruminal parameters. Animal Feed Science and Technology, 226(4), 5664. doi: 10.1016/j.anifeedsci.2016.12.006
Siqueira, M. C. B., Ferreira, M. A., Monnerat, J. P. I. S., Silva, J. L., Costa, C. T. F., Conceição, M. G.,... Chagas, J. C. C. (2018). Nutritional performance and metabolic characteristics of cattle fed spineless cactus. Journal of Agricultural Science and Technology, 20(1), 13-22. Recovered from http://jast.modares.ac.ir/article-2311336-en.html

Soares, C., Rocha, V.R., Jr., Monção, F.P., Borges, L. D. A., Caldeira, L. A., Costa, N. M.,... Chamone, J. M. A. (2020). Combinations of cactus pear with different roughage sources on the production, chemical composition, and milk fatty acid profile of F1 Holstein/Zebu cows. Tropical Animal Health and Production, 52(5), 2567-2576. doi: $10.1007 / s 11250-020-02290-x$

Valadares, S. C., F., \& Valadares, R. D. F. (2001). Recentesavanços em proteína na nutrição de vacas leiteiras. Anais do Simpósio Internacional em Bovinocultura de Leite, SINLEITE, Simpósio Internacional: Novos Conceitos em Nutrição, Lavras, MG, Brasil.

Weiss, W.P.(1999). Energy prediction equations for ruminant feeds. Proceedings of the Cornell Nutrition Conference Feed Manufactures, Ithaca, NY, EUA, 61. 